Siedina, Giovanna, ed. Latinitas in the Polish Crown and the Grand Duchy of Lithuania: Its Impact on the Development of Identities. Firenze: Firenze University Press Penguin Press, 2014

Reviewed by: Olha Tsyhanok

Source: Kyiv-Mohyla Humanities Journal 2 (2015):167-169

Published by: National University of Kyiv-Mohyla Academy

http://kmhj.ukma.edu.ua/ 


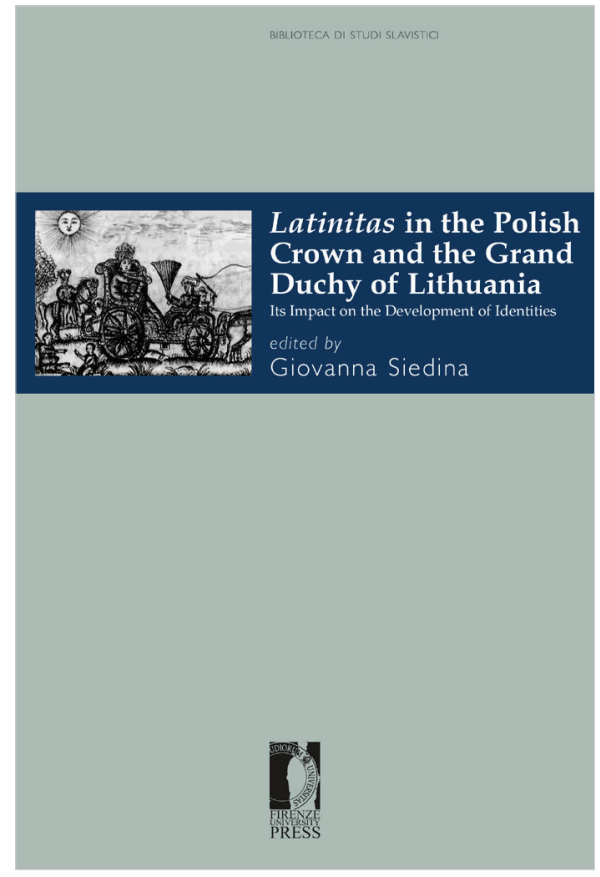

Giovanna Siedina, ed.

\section{Latinitas in the Polish Crown and the Grand Duchy of Lithuania: Its Impact on the Development of Identities}

Firenze: Firenze University Press Penguin Press, 2014. $178 \mathrm{pp}$.

ISBN: 978-88-6655-674-9

\section{Reviewed by Olha Tsyhanok}

In the study of early-modern Ukrainian literature, the heritage of the 17th-18th centuries requires particular attention. If we compare the number of literary works written in these centuries in Ukraine with the literary legacy of the previous centuries, the difference is striking. The elite literature of that time was particularly important since it was oriented to the decisionmakers. However, due to ideological constraints of various types, little research was devoted to this literary output in the 19th-2oth centuries.

The "high" secular literature spanning the 16th - first half of the 17th century was written mainly in Latin. The articles collected in the book Latinitas in the Polish Crown and the Grand Duchy of Lithuania: Its Impact on the Development of Identities range from history to literature and to cultural history and the history of ideas. They analyse the issue of building an identity, either real or imagined, from different points of view. Both the topic and the authors' approaches can be considered a novelty in the scholarly horizon of this research area.

The need to study the Neo-Latin literature of the aforementioned period in "cooperation," so to speak, derives from the fact that the early-modern literature of the stated area was produced by a broader cultural community. This is rightly observed by the editor of the book, Giovanna Siedina, in her Introduction: "Only in recent years has it been studied from an areal point of view, and not only anachronistically in a modern 'national' key" (p. 11). In the 16th-18th centuries, Ukraine was a part of two larger cultural communities. The first was constituted by the Polish Crown and the Grand Duchy of Lithuania (Rzecz Pospolita). The second was the Russian Empire. Accordingly, the history of early-modern Ukrainian literature needs to be studied as a component of the literary process of these cultural communities. It is not always possible to trace their borders on the map, although the political situation significantly influenced the spiritual and cultural orientation. Awareness of belonging to this or that other commonwealth for contemporary educated people was as important as their "little homeland." 
The article by Sigitas Narbutas on Latinitas in the Grand Duchy of Lithuania ("Chronology, Specifics and Forms of Reception") has a programmatic character in the book. The scholar thinks that "Latinitas may be considered as a perspective topic for future research" (p. 145). Sigitas Narbutas provides some interesting statistics regarding the number of books, and their topics, printed in Latin in the 16th-18th centuries within the Grand Duchy of Lithuania and also abroad by its citizens over this period. "In eighteenth-century Lithuania most of the literature published in Latin consisted of panegyrical publications, followed by salutatory, epithalamic and funereal texts" (p. 152). In this sense, it is no coincidence that the authors of some of the articles focused their attention on poems "for a certain occasion," on panegyrics in the broad sense of this word, which here and there already from the time of Lucan and Statius (1st century A.D.) were called silvae. Regrettably, there are no wide-ranging studies (monographs) on these issues.

Two articles in this miscellany are devoted to epic poetry. Jakub Niedźwiedź assesses the impact of the classical epic tradition on the image of Lithuania and the self-image of its inhabitants in the sixteenth century. Žanna Nekraševič-Karotkaja analyses epic poetry in Latin as a factor in the cultural identity of Central and Eastern Europe in the 16th-18th centuries. The scholar has authored a monograph on Belarusian Neo-Latin poetry of the late Renaissance and early Baroque (Minsk, 2011).

Žanna Nekraševič-Karotkaja rightly points to the evolution of epic poetry, to its link with panegyric poetry. However, panegyrics intersected with epic poetry only partly. Depending on the "status" of the main character, panegyrics could belong to epic poetry, to lyrics and, if we keep in mind that in 17th-century poetics elegy was often considered as a separate literary genre, also to elegy. Panegyrical epos was written in dactylic hexameters, was relatively long and was dedicated to people of lofty status (holy people, kings, princes, etc.).

Valerii Shevchuk believes that the Latin panegyrics of Pavlo Rusyn from Krosno, published in Vienna in 1509, dedicated to Saint Stanislav and to King Vladislav of Hungary, were the first Ukrainian epic poems. Panegyrical elegy was written in elegiac distichs, was average in length (about 200 lines), celebrated a person of lower status (for instance, the main character of one poem by Pavlo Rusyn from Krosno was the king's doctor). Numerous relatively short panegyrics were devoted both to protectors, and to close people and were written mainly in the meters of lyric poetry. It is important to study just how popular panegyric epos was in the Polish Crown and the Grand Duchy of Lithuania in the 16th-18th centuries. A general idea of this is provided by bibliographies, descriptions of old prints, and the like (Nowy Korbut, the catalogue by Zapasko and Isaievych among others). In this respect, Žanna Nekraševič-Karotkaja very usefully studied the old prints preserved in Minsk's libraries and archives. In this respect, the article of Žanna Nekraševič-Karotkaja stimulates further research.

Alexandr Osipian has analysed uses of Cornelius Tacitus's Germania and Annales in J. B. Zimorowicz's Leopolis Triplex (1650s-1670s). The article contributes to research into the worldview of the 17th-century urban elite, including their understanding of how the past was reshaped for present purposes.

Aleksander Wojciech Mikołajczak investigates ancient and Christian traditions in the Latin poetry of Renaissance and Baroque Poland. Practically the scholar has provided a review of Polish-Latin poetry up to the middle of the eighteenth century. Referring to Jerzy Axer, Mikołajczak writes that "paradoxically, the influence of Polish latinitas spread further than 
ever in Central and Eastern Europe" (p. 75). We would like to point out that in the first half of the eighteenth century Polish influence in Ukraine gradually diminishes, and the Neo-Latin literature created in this period, although more modest than that of Catholic countries, appears more "original."

Valentyna Myronova's article "The Chancellery Latin in Fifteenth-Sixteenth Century Ukraine" presents the state of research on this topic and analyses the linguistic characteristics of the Latin language of Galician Rus. The material for this analysis consists of the record books of the Grodskyi and Zemskyi courts of Galician Rus, published in 1886-1889 in Lviv.

Giovanna Siedina analyses the teaching of lyric meters and the reception of Horace in KyivMohylanian poetics. The reception of Horace in Ukrainian Neo-Latin literature is an important topic, to which so far only Siedina has devoted scholarly efforts in some depth.

Quite a few articles in the miscellany mention Horace's talented follower, the Polish Jesuit Maciej Kazimierz Sarbiewski (1595-1640), one of the most eminent Neo-Latin poets in Europe. On the basis of Sarbiewski's poetry, Piotr Urbański investigates cultural and national identity in Jesuit Neo-Latin poetry in Poland in the seventeenth century. The scholar convincingly proves that the ideas of some Polish and Lithuanian researchers on Sarbiewski's sarmatism and, consequently, his national identity, are mistaken. The concept of Horatius Sarmaticus is a creation of Romanticism and is still "alive." A similar phenomenon can be observed in the study of early-modern Ukrainian literature, which, until recently, has often been hostage to selfperpetuating stereotypes. As regards Sarbiewski, above all he felt himself to be European and adopted a Classical (Roman) and Christian system of values. However, it should be noted that the definition Horatius Sarmaticus may refer not to the identity of Sarbiewski, but rather to a "geographical" attribute, and, to a certain extent, in this sense it would be correct.

It is worth noting here that there are unfortunately no translations of Sarbiewski's poetry into Ukrainian. Andrii Sodomora, Horace's eminent translator into Ukrainian, could profitably tackle this task. Such a translation would constitute a milestone in the popularization of NeoLatin and Jesuit poetry in Ukraine, interest in which is growing in contemporary literary studies.

All in all, the miscellany examined in this review is an important contribution to the study of Latinitas and identity in the Polish Crown and the Grand Duchy of Lithuania, which is just beginning. We hope that the new perspectives opened by the areal approach that this trailblazing collection of articles espouses, will soon give birth to further scholarly research and research projects on this and similar topics. 